\title{
TRADUÇÃO E INTRODUÇÃO DAS OBRAS DE MACHADO DE ASSIS NA CHINA
}

\section{ZHIHUA HU}

Universidade de Aveiro

Aveiro, Portugal

\section{MARIA TERESA ROBERTO}

Universidade de Aveiro

Aveiro, Portugal

Resumo: Como um dos mais importantes escritores do Brasil, Machado de Assis já tem várias obras traduzidas e introduzidas na China. Entretanto, ainda são escassos os estudos literários e os estudos de tradução e introdução das suas obras naquele país. Pelo presente trabalho, realizaremos um percurso retrospectivo das obras machadianas traduzidas na China. O nosso corpus é composto de três traduções chinesas: Quincas Borba, por Sun Cheng'ao; Dom Casmurro e Contos escolhidos, por Li Junbao. Mediante as análises dessas obras e com base nos conceitos de "domesticação" e "estrangeirização" de Venuti (1995), pretendemos sintetizar e comparar as estratégias tradutológicas adotadas pelos tradutores nas versões chinesas e também indicar as características dessas traduções. Depois da análise, descobrimos que os tradutores adotam estratégias diversas e os textos-alvo apresentam também características distintas, aproximando ou afastando seus leitores da cultura-fonte.

Palavras-chave: Machado de Assis; tradução das obras machadianas na China; estudo das obras machadianas na China.

Abstract: As one of the most important writers in Brazil, several of Machado de Assis's works have already been translated into Chinese. Considering the literary value 
of Machado's work, literary and translation studies of his works, as well as their presence, are still very scarce in China. Through this article, we will glance back in time at as we consider the works of Machado de Assis translated in China; in fact, a translation analysis will also be carried out for versions in Chinese. Our corpus is made up of three Chinese translations (Quincas Borba, translated by Sun Cheng'ao, and Dom Casmurro and Contos Escolhidos by Li Junbao). Through our analysis based on Venuti's (1995) strategies of "domestication" and "foreignization," we will endeavour to dissect and compare the translation strategies adopted by the translators in the Chinese versions; moreover, we will also point out other aspects that characterize the translations. After our analysis, we found that the translators did not always adopt the same strategies and that the texts in the target language also have differing characteristics, which bring readers closer to or further away from the source culture.

Keywords: Machado de Assis; translation of works of Machado de Assis in China; study of the works of Machado de Assis in China.

\section{Introdução}

omo um dos mais importantes escritores do Brasil, Machado de Assis já tem muitas obras traduzidas e introduzidas em diversos países. Embora até agora já tenham surgido muitas análises sobre as suas obras no mundo lusófono, os estudos das suas obras e as respetivas traduções e introduções na China ainda são escassos. A maior representação do estudo das suas obras consta em Literatura brasileira, de Sun Cheng'ao (1999), tradutor do romance Quincas Borba. Aqui, a maioria dos estudos relacionados com as produções machadianas dá conta da recepção e análise dos enredos das suas obras representativas (Memórias póstumas de Brás Cubas, Quincas Borba e Dom Casmurro), que, segundo Sun (1999), demonstram plenamente as características dos romances realistas do estilo machadiano e incorporam ideias criativas e os talentos artísticos do escritor. No que concerne à tradução e introdução das obras machadianas, até o presente, os leitores chineses já têm acesso a quatro delas, nomeadamente, Memórias póstumas de Brás Cubas; Quincas Borba; Dom Casmurro; e Contos escolhidos: o alienista e outras estórias (sendo a última uma coletânea). 
Este trabalho constitui um estudo de caso da tradução e introdução das obras machadianas na China, tentando responder às seguintes questões: Quais são as obras de Machado de Assis traduzidas para o chinês? Que estratégias tradutológicas são adotadas nas versões chinesas?

Concretamente, o trabalho divide-se em três partes: a primeira procura explorar a introdução das obras machadianas na China; a segunda parte irá discutir as estratégias de transposição adotadas nas traduções; a última parte apura uma conclusão da nossa análise das traduções e da introdução de algumas obras literárias machadianas.

\section{Sobre a tradução e a introdução das obras machadianas na China}

Embora não existam muitas obras brasileiras introduzidas na China, com os inestimáveis esforços dos tradutores, as produções representativas dos escritores mais importantes começam a ser acessíveis. Quanto à tradução das obras de Machado de Assis, há, até o presente: a Trilogia realista de Machado de Assis, constituída pelos romances que marcaram a introdução do estilo realista nas obras do autor, a saber, Memórias póstumas de Brás Cubas, Quincas Borba e Dom Casmurro, publicada em 1992 pela editora Lijiang e traduzida por Wengyilan, Li Shulian e Jing Qinsun; Quincas Borba, publicado em 1999 pela Shanghai Translation Publishing House e traduzido por Sun Cheng'ao; Dom Casmurro, publicado em 2001 pela Foreign Language Publishing House e traduzido por Li Junbao; Contos escolhidos: o alienista e outras estórias, publicado em 2004 pela People's Literature Publishing House e traduzido por Li Junbao. Como se sabe, desse conjunto Quincas Borba, Memórias póstumas de Brás Cubas e Dom Casmurro são romances, e Contos escolhidos: o alienista e outras histórias uma antologia que inclui seis contos ("O Alienista", "O Espelho", "Um Homem Célebre", "A Causa Secreta", "O Enfermeiro" e "Pai Contra Mãe") retirados de três coletâneas de contos (Papéis avulsos, de 1882, Várias histórias, de 1896, e Relíquias da casa velha, de 1906). Quanto aos tradutores da Trilogia realista, ainda não conseguimos encontrar informações referentes a eles; por este motivo, e tendo em conta tanto a indisponibilidade da tradução, como os limites deste artigo, não iremos analisá-la. A lacuna criada pela escolha será colmatada em trabalhos futuros. 


\section{Sobre a tradução e a introdução da obra Quincas Borba}

Sun Cheng'ao, tradutor de Quincas Borba, foi professor de português da Universidade de Línguas Estrangeiras de Pequim. Depois da sua formação pela mesma universidade em 1966, começou a trabalhar como professor e, em 1982, foi estudar literatura brasileira e portuguesa na Universidade de Campinas. Em 1984, foi transferido para o Instituto de Literatura Estrangeira e, de 1987 a 1992, trabalhou na Embaixada da China em Portugal. Entre 1993 e 1995, trabalhou na Universidade de Macau. Atualmente é vice-diretor do Instituto de Literatura Estrangeira da Universidade de Línguas Estrangeiras de Pequim e diretor da Associação da Literatura Espanhola, Portuguesa e Latino-americana da China (APRESENTAÇÃO..., on-line). No âmbito da tradução e introdução das obras brasileiras, este tradutor tem gozado de uma reputação incontestável, cujas traduções incluem obras de Jorge Amado, Machado de Assis, Rachel de Queiroz e Paulo Coelho. Além disso, ele também publicou a monografia Literatura brasileira (CHENG'AO, 1999) e participou da elaboração da seção referente à literatura brasileira do livro História da literatura latino-americana (JINGDONG; CHENG'AO, 2004).

É-nos difícil saber quais foram as razões que motivaram a decisão de Cheng'ao de traduzir o romance Quincas Borba. No entanto, se lançarmos um olhar cronologicamente retrospectivo às suas traduções, talvez possamos obter algumas pistas. Em 1985, foi publicada a sua primeira tradução, Gabriela, cravo e canela, de Jorge Amado (1985), cuja nota da editora indica que a obra foi integrada numa coletânea de literatura estrangeira, por meio da qual os leitores seriam capazes de conhecer as mudanças históricas, a evolução dos pensamentos sociais e a herança e o desenvolvimento da literatura dos países estrangeiros. O prefácio, escrito pelo tradutor, aponta que a razão pela qual a obra ficou famosa seria o fato de ela refletir os pensamentos progressistas, isto é, a luta entre a força progressista e a força conservadora, e ter um enredo complexo e fascinante, sendo os retratos das personagens muito intensos e detalhados. Com tudo isso, pode-se apurar a razão pela qual as obras de Jorge Amado foram traduzidas e introduzidas naquela época na China: por um lado, por força dos valores artísticos incontestáveis da dita obra, por outro lado, pelos pensamentos ideológicos coincidentes com os que vigoravam na China naquela altura. 
Depois dessa tradução de Gabriela, cravo e canela, em 1999, foi lançada a tradução de Quincas Borba (ASSIS, 1999), cujo prefácio, igualmente pelo tradutor, indica a biografia do autor, o enredo da obra e comentários do tradutor. Segundo o prefácio, com pinceladas humorísticas, o autor revelaria vivamente, diante dos leitores, as atividades psicológicas das personagens e os fenômenos sociais daquela época, levando os leitores a uma reflexão profunda. Aliás, o prefaciador acrescenta que o conteúdo profundo, a descrição psicológica, a unidade de forma e conteúdo, e a linguagem precisa e humorística, em conjunto, fazem de Quincas Borba uma obra clássica de Machado de Assis. Pelo que se indica acima, observa-se que Cheng'ao, nesse prefácio, já não se detém apenas nas críticas sociais, como fez na tradução anterior da obra de Jorge Amado. Em vez disso, os comentários dão mais destaque aos valores artísticos do romance e, desse modo, o tradutor procura despertar o interesse dos leitores. Além disso, ao tratar dos obstáculos enfrentados na tradução, Cheng'ao afirma que as dificuldades resultaram principalmente das abundantes citações das obras clássicas da história e da literatura ocidental. Para ele, em Quincas Borba, Machado de Assis incluiu referências a muitos acontecimentos históricos e lançou mão da intertextualidade com obras literárias do mundo ocidental, conferindo, dessa maneira, uma grande densidade cultural e valor artístico à obra, porém criando também dificuldades para os tradutores não familiarizados com essas citações e com os intertextos do aporte cultural ocidental.

Com o objetivo de verificar como o tradutor resolveu o problema das citações na tradução, dado o limite do espaço deste artigo, iremos analisar apenas alguns exemplos ilustrativos.

Concretamente, as análises dividem-se em duas partes, sendo a primeira enfocada nas explicações dadas pelo tradutor no que respeita às citações do texto-fonte e a segunda concentrada em outras práticas realizadas pelo tradutor. Quanto à segunda parte das análises, as traduções serão avaliadas com base nas estratégias de Domesticação e Estrangeirização. Segundo Venuti (1995, p. 20), Domesticação consiste em aproximar o autor da cultura da língua-alvo, enquanto que Estrangeirização em aproximar os leitores da cultura exótica da língua-fonte, aceitando as diferenças linguísticas e culturais. Com a Domesticação, os conflitos culturais podem ser evitados, facilitando a divulgação e a recepção da cultura-fonte na cultura-alvo; com a Estrangeirização, pode-se proporcionar aos leitores um ângulo visual muito distinto e, desse modo, beneficiam-se os intercâmbios entre países e povos e, ao mesmo tempo, enriquecem-se as 
línguas de chegada. Além da análise da adoção dessas estratégias pelo tradutor, também iremos procurar se existem outros mecanismos tradutórios por ele operados.

Através do estudo da tradução, observamos que o tradutor ofereceu abundantes explicações sobre as citações nas notas de rodapé, que se classificam nas seguintes categorias:

(1). Citações sobre os antropônimos:

A. "[...] assim se explica este par de figuras que aqui está na sala, um Mefistófeles e um Fausto [...]" (ASSIS, 1984, p. 6). Considerando que é provável os leitores chineses não saberem a quem se referem as figuras citadas, o tradutor mudou "Mefistófeles" para "o diabo Mefistófeles". Já para o nome "Fausto", o tradutor recorreu a uma nota de rodapé, explicando que "Fausto" é o protagonista da obra homônima do escritor alemão Goethe, e que "Mefistófeles" é o diabo na mesma obra.

(2). Citações sobre os topônimos:

A. "[...] por mais que lhe dissesse que estava acostumado aos seus crioulos de Minas [...]" (ASSIS, 1984, p. 6, grifo nosso). Para a palavra em itálico, o tradutor fornece uma explicação, indicando que se trata da abreviatura do estado de Minas Gerais.

(3). Alusão a outras obras de Machado de Assis:

A. "Este Quincas Borba, se acaso me fizeste o favor de ler as Memórias póstumas de Brás Cubas [...]" (ASSIS, 1984, p. 8). Sobre a parte em itálico, o tradutor explicou, em rodapé, que se trata de outra obra do autor. Além disso, ele também expôs um pouco sobre o conteúdo e o estilo de narrativa da obra citada.

B. "Dona Tonica sentiu o grasnar do velho corvo da desesperança. Quoth the Raven: NEVER MORE" (ASSIS, 1984, p. 54). Segundo o tradutor, aqui se trata de uma referência ao poema "O Corvo" de Edgar Allan Poe, traduzido por Machado de Assis.

Para além dos exemplos mencionados, para algumas palavras com pendor cultural mais forte, o tradutor também trouxe explicações em notas de rodapé. Vejamos brevemente alguns exemplos:

A. "Calculou o algarismo. Menos de dez contos, não. [...]" (ASSIS, 1984, p. 21, grifo nosso). Notas tradutórias: moeda brasileira. 
B. "Sabe que era um modo de engrossar a perna [...]" (ASSIS, 1984, p. 49, grifo nosso). Notas tradutórias: naquela época, as pessoas consideravam as pernas grossas como um símbolo de beleza.

Embora não tenha indicado os métodos tradutórios que preferiu usar na tradução, na sequência da nossa análise encontramos alguns aspectos que podem elucidar os procedimentos tradutórios. Vejamos:

(4). Domesticação:

A. "Ia mostrá-la, recuou e meteu-a no bolso. Estava fora de si, meio confuso, meio alegre; [...]" (ASSIS, 1984, p. 46, grifo nosso). A parte em itálico foi traduzida para uma expressão típica da cultura chinesa, que tem a denotação "o coração como um macaco e a mente como um cavalo inquieto" e a conotação "inquieto e ser propenso a atrações externas".

B. "O pior é que ele despendia todo o ganho e mais. [...]" (ASSIS, 1984, p. 51, grifo nosso). A parte em itálico foi traduzida para uma expressão típica da cultura chinesa, que tem a denotação de "jogar dinheiro como lama" e a conotação de "gastar dinheiro sem limite".

C. "Era homem de muito saber, e cansava-se em batalhar contra esse pessimismo amarelo e enfezado que ainda nos há de chegar aqui um dia [...]" (ASSIS, 1984, p. 22, grifo nosso). Na tradução, a cor "amarelo" foi traduzida para "pálido". Levando em conta que o adjetivo "enfezado" significa "fraco", o tradutor recorreu a uma expressão chinesa muito corrente: "pálido e fraco". Embora o significado da palavra "amarelo" tenha sido mudado, o sentido principal do conjunto lexical "amarelo e enfezado" foi mantido. A nosso ver, a mudança da cor "amarelo" também tem a ver com a adaptação cultural: a palavra "amarelo" tem a tendência de ser uma forma disfêmica de se referir a pessoas dos países orientais, conotação que o tradutor tentou evitar ao efetuar essa mudança.

(5). Estrangeirização:

A. "Rubião agarrou-se às eleições próximas; mas aqui interveio Camacho, afirmando que não era preciso, que a serpente devia ser esmagada cá mesmo na capital [...]" (ASSIS, 1984, p. 93, grifo nosso). A parte em itálico foi traduzida com o método de tradução literal, sem nenhuma explicação sobre a conotação da expressão, fato que cria muita confusão nos leitores

${ }^{1}$ Retradução do chinês para o português nossa. 
não-ocidentais. A imagem "serpente esmagada" está fortemente relacionada com os relatos da Gênesis da Bíblia: "Porei ódio entre ti e a mulher", diz o Criador à serpente, "entre a tua descendência e a dela. Esta te ferirá a cabeça, e tu lhe ferirás o calcanhar" (QUEM..., 2012). É bem provável que muitos leitores chineses não consigam relacionar aqui a "serpente esmagada" com a "serpente" da Bíblia, caso em que, a nosso ver, conviria oferecer informações explicativas em nota de rodapé.

\section{Sobre a tradução e a introdução da obra Dom Casmurro}

A tradução de Dom Casmurro dispõe de dois prefácios. O primeiro foi escrito pelo embaixador do Brasil na China, Afonso Celso Ouro Preto, indicando, concretamente, tanto aspectos biográficos como elementos característicos da obra.

Sobre a biografia e a carreira profissional de criação literária de Machado de Assis, segundo o embaixador, na primeira fase da sua criação, as obras consistiriam principalmente em contos, poemas românticos, poemas indígenas e fantasias românticas; na segunda fase, elas incluem contos, poemas parnasianos e romances. Contrariamente às obras românticas da primeira fase, os romances pós Brás Cubas usariam mais pinceladas realistas e observações psicológicas exatas no retrato das diferentes facetas da sociedade do Rio de Janeiro de então. Ele aponta ainda que essa segunda fase coincide com um período difícil da vida de Machado de Assis, que, atormentado por problemas de saúde, percebeu a dor da vida humana profundamente e, com isso, a sua criação também desenvolveria as seguintes características: amargura, suspeita, sarcasmo, decepção com os homens, perda de confiança e uma observação perspicaz das almas das pessoas. Dom Casmurro pertence aos trabalhos desse período.

Já acerca do enredo de Dom Casmurro e de suas qualidades artísticas, o prefaciador sublinha a presença de abundantes metáforas, imagens particulares, provérbios (cujos correspondentes são muito difíceis de ser encontrados em chinês) e de linguagem ambígua (que abre espaço para a complexidade da compreensão). Segundo o embaixador, tudo isso apresenta uma tarefa desafiadora para os tradutores.

O outro prefácio foi elaborado pelo Prof. Zhao Deming, da Universidade de Pequim. De acordo com a sua perspectiva, a mudança da 
criação de Machado de Assis do romantismo para o realismo representaria uma dúvida quanto aos valores dessa escola estética e uma transição de atitude na sua aprovação dos fenômenos sociais (da confiança cega na prosperidade da sociedade de então para a dúvida com relação à racionalidade do sistema social), o que exigiria uma coragem e inteligência inimagináveis. Em Dom Casmurro, segundo Deming, o autor aproveitou habilmente a psicologia, dissecando delicada e profundamente os aspectos complexos do mundo interior do personagem principal.

Além dos prefácios citados, a tradução possui duas partes dedicadas cada uma, respectivamente, à descrição breve do enredo da obra e a uma biografia do autor, sendo que, na parte referente ao enredo da obra, há também comentários sobre a tradução.

De maneira geral, considera-se que a tradução do romance é fluente, especialmente no que concerne à descrição do amor no livro, que é sutil e expressiva, embora contenha comentários subjetivos. Aliás, vários estudiosos chineses apresentaram também as suas considerações sobre essa obra. Sun Cheng'ao (1999, p. 85) indica que sua estrutura e organização são muito bem elaboradas e a linguagem é simples e acessível. Para ele, a parte mais fascinante estaria nas descrições psicológicas, já que a linha principal que atravessa a obra inteira consiste nas mudanças psicológicas do protagonista quando ele começou a duvidar da relação entre a sua mulher e o seu melhor amigo. Sun Shan (2016), além de destacar o valor artístico das descrições psicológicas, foca especialmente o despertar da consciência feminina na obra. De acordo com Shan, Capitu tentou encontrar uma saída quebrando a escravidão tradicional e desafiando o estilo de vida das mulheres do século XIX. No entanto, Bento não tolerou a busca do eu por parte da sua esposa: o sistema de discurso patriarcal e a ideologia do indivíduo feminino eram incompatíveis na sociedade daquela época.

No prefácio dessa tradução, não se encontra nenhuma informação sobre o tradutor, porém, no prefácio de outra tradução sua - $O$ alienista $e$ outras histórias (ASSIS, 2004) - é possível conhecer um pouco sobre sua trajetória. Li Junbao era um tradutor e editor da Foreign Language Publishing House que, nos primeiros anos da sua carreira profissional, traduzia principalmente do russo para o chinês na área de técnica industrial. Começou a estudar português em 1960 e, após sua graduação, dedicou-se à tradução do chinês para o português e vice-versa. Em 1997, foi premiado com a Medalha Oficial pelo então Presidente da República de Portugal, Jorge Sampaio. 
No processo de nos informarmos sobre a tradução de Li, descobrimos que nem a tradução de Dom Casmurro nem a de $O$ alienista e outras histórias menciona os métodos tradutórios adotados por ele, além de também não se conseguir encontrar relatos sobre os problemas enfrentados durante a tradução. Dado isso, realizaremos uma análise das traduções de Li no intuito de explorar algumas características tradutórias por ele seguidas.

(1). Explicações das citações:

Distintas das explicações de Sun Cheng'ao, as explicações de Li Junbao não estão nas notas de rodapé; em vez disso, figuram todas entre parênteses, imediatamente depois das palavras a serem esclarecidas para os leitores. As explicações focam nas seguintes categorias: antropônimos, topônimos, literatura, mitologia e cultura. Vejamos alguns exemplos:

A. "'Vou para Petrópolis, Dom Casmurro; a casa é a mesma da Renânia; [...]'" (ASSIS, 1998, p. 7, grifo nosso). Notas tradutórias: cidade brasileira com paisagem bonita (topônimo).

B. "Dom veio por ironia, para atribuir-me fumos de fidalgo. [...]"(ASSIS, 1998, p. 7). Notas tradutórias: "Dom", título da antiga aristocracia, tratamento para os homens de status social elevado, equivalente a "Senhor" (cultura).

C. "[...] como ninguém tachou de má a boceta de Pandora, por lhe ter ficado a esperança no fundo; [...]" (ASSIS, 1998, p. 14, grifo nosso). Notas tradutórias: uma caixa oferecida a Pandora pelo deus principal Júpiter, na mitologia romana, que contém vários desastres humanos (mitologia).

D. "Não, a imaginação de Ariosto não é mais fértil que a das crianças e dos namorados, [...]" (ASSIS, 1998, p. 40, grifo nosso). Notas tradutórias: poeta renomado na época do Renascimento (antropônimo).

(2). Domesticação e estrangeirização:

A. "Ah! como eu sinto não ser um poeta romântico para dizer que isto era um duelo de ironias! Contaria os meus botes e os dela, a graça de um e a prontidão de outro, e o sangue correndo, e o furor na alma, [...]" (ASSIS, 1998, p. 61, grifo nosso). A parte em itálico foi traduzida para "pistola de lábios e espada de línguas" em chinês, ${ }^{2}$ expressão idiomática viva que serve para descrever o caso em que uma pessoa luta com outra verbalmente (domesticação).

\footnotetext{
${ }^{2}$ Retradução do chinês para o português nossa.
} 
B. "Minha mãe assoou-se sem responder. Prima Justina creio que se levantou e foi ter com ela. Seguiu-se um alto silêncio, durante o qual estive a pique de entrar na sala, mas outra força maior, outra emoção..." (ASSIS, 1998, p. 10, grifo nosso). A parte em itálico foi traduzida para "nem um corvo nem um pardal pode ser ouvido", expressão típica em chinês ${ }^{3}$ que descreve uma situação em que ninguém fala (domesticação).

C. "Com o tempo, adquiriu certa autoridade na família, certa audiência, ao menos; não abusava, e sabia opinar obedecendo." (ASSIS, 1998, p. 12, grifo nosso). A parte em itálico foi traduzida para a expressão idiomática "as estrelas mudam de posição", em chinês, ${ }^{4}$ significando "mudança das estações; passagem do tempo" (domesticação).

D. "A fortuna troca muita vez as mãos à natureza" (ASSIS, 1998, p. 13, grifo nosso). A parte em itálico foi traduzida para "fica no este por trinta anos e fica no oeste por trinta anos", uma expressão muito típica em chinês, ${ }^{5}$ simbolizando "a vida está cheia de bons e maus momentos e ninguém pode predizer o futuro" (domesticação).

Não escasseiam na obra exemplos como os citados, nos quais o tradutor recorreu à domesticação, aproximando o texto-fonte dos leitores. Porém, isso não significa que o tradutor não tenha adotado a estrangeirização: depois da pesquisa, descobrimos que esse procedimento se reflete nas estruturas frásicas do chinês. Vejamos os exemplos seguintes:

E. "A mim é que ele me denunciou." (ASSIS, 1998, p. 18)

"对我他 做了举报。”(ASSIS, 2001, p. 23) (estrangeirização na estrutura frásica).

A mim ele fez denúncia (tradução palavra por palavra).

Como se vê, a estrutura frásica chinesa acima citada é quase igual à portuguesa, embora a estrutura frásica normal devesse ser a seguinte:

他 对 我 做了 举报。

Ele a mim fez denúncia (tradução palavra por palavra).

\footnotetext{
${ }^{3}$ Retradução do chinês para o português nossa.

${ }^{4}$ Retradução do chinês para o português nossa.

${ }^{5}$ Retradução do chinês para o português nossa.
} 
F. "- Que é que você tem?" (ASSIS, 1998, p. 21)

"你今天 发生了什么事?" (ASSIS, 2001, p. 29) (estrangeirização na estrutura frásica).

Você hoje haver (ter) quê (tradução palavra por palavra).

Como se vê, a estrutura frásica chinesa aqui citada é novamente muito semelhante à portuguesa. ${ }^{6}$ Contudo, a estrutura frásica normal deveria ser a seguinte:

你 今天 怎么了?

Você hoje como (tradução palavra por palavra).

No que respeita à aproximação com as estruturas frásicas de língua portuguesa, na versão chinesa também existem muitos casos em que essas influências se refletem. Com base nisso, concluímos que, embora muitas palavras e expressões tenham sido domesticadas na tradução, nota-se uma representação da estrangeirização quando da tradução de algumas das estruturas frásicas.

\section{(3). Ampliação:}

O método de ampliação reflete-se mais na tradução dos títulos de cada capítulo, que, a nosso ver, já não se pode considerar apenas como uma aplicação das estratégias de domesticação e de estrangeirização; em vez disso, tais casos podem ser encarados como uma intervenção ativa do tradutor. Contrariamente à domesticação (embora esta também possa ser considerada como uma intervenção do tradutor), o emprego do método de ampliação muitas vezes muda a ideia do texto original, acrescentando mais informações do que o autor queria expressar, ao passo que o uso da domesticação não acrescenta informações irrelevantes, aproximando apenas o texto original dos leitores. Vejamos alguns exemplos: ${ }^{7}$

A. "É TEMPO" (ASSIS, 1998, p. 15), título do capítulo VIII, que foi traduzido para o chinês como "O início da viagem da vida".

B. "A ÓPERA" (ASSIS, 1998, p. 15), título do capítulo IX, que foi traduzido para o chinês como "A vida é como uma ópera".

Por meio desses casos, observa-se que o tradutor acrescentou informação aos títulos originais, procurando resumir o conteúdo de cada capítulo com uma frase do texto original ou com as suas próprias palavras.

\footnotetext{
${ }^{6} \mathrm{O}$ advérbio ou pronome interrogativo costuma ficar no final das frases chinesas. Nesse exemplo, vê-se que, com exceção do pronome interrogativo "quê", o resto é semelhante à estrutura frásica da língua portuguesa.

${ }^{7}$ Retraduções do chinês para o português nossas.
} 
Por exemplo, para o título "É TEMPO", no mesmo capítulo, encontra-se a frase "Verdadeiramente foi o princípio da minha vida" (ASSIS, 1998, p. 15); e para "A ÓPERA", há a frase "A vida é uma ópera e uma grande ópera" (ASSIS, 1998, p. 16), que foi tomada como título pela tradução.

(4). Mudança:

A adoção de "mudança" é também muito frequente na tradução dos títulos de cada capítulo. Tal como o procedimento de ampliação, o método de mudança, a nosso ver, também deve ser considerado uma intervenção ativa do tradutor, já que as informações transmitidas pelo texto-fonte mudam. O método de mudança não se confunde com o uso da estratégia de domesticação que, embora altere as informações do texto-fonte, mantém suas informações principais. Além disso, essas alterações operadas pela domesticação partem do ponto de vista dos leitores do texto-alvo, ou seja, as alterações (linguísticas, culturais) são necessárias para deixar o texto-fonte mais acessível aos leitores do texto-alvo. Vejamos alguns exemplos: ${ }^{8}$

A. "MIL PADRE-NOSSOS E MIL AVE-MARIAS" (ASSIS, 1998, p. 31), título do capítulo XX, traduzido para o chinês como "Empenhar a alma".

B. "IDEIA SEM PERNAS E IDEIA SEM BRAÇOS" (ASSIS, 1998, p. 50). título do capítulo XXXVI, traduzido para o chinês como "Beijá-la, que foi só uma ideia".

C. "A ALMA É CHEIA DE MISTÉRIOS" (ASSIS, 1998, p. 51), título do capítulo XXXVII, traduzido para o chinês como "Ela é uma pessoa cheia de mistérios".

D. "ABANE A CABEÇA, LEITOR" (ASSIS, 1998, p. 62), título do capítulo XLV, traduzido para o chinês como "Minha dor".

Comparando os títulos originais e as traduções, nota-se que são criações do próprio tradutor com base nos conteúdos de cada capítulo, ou seja, não são criações gratuitas. Todas as traduções consistem em resumos de cada capítulo, mudança que ajuda os leitores a perceber rapidamente o tema principal de cada parte do romance e atenua, ou elimina, associações de natureza religiosa ou espiritual.

${ }^{8}$ Retraduções do chinês para o português nossas. 
Diferentemente das traduções mencionadas anteriormente, essa tradução possui uma parte dedicada à biografia do tradutor, cujo conteúdo já foi referido no item "Sobre a tradução e introdução da obra Dom Casmurro". Também existe, na tradução, uma nota do editor, uma introdução, um prefácio e uma nota do patrocinador. Da nota do editor, constam principalmente a biografia do autor, as características da escrita e a composição do volume, indicando que ele se compõe de seis contos, pertencentes a três coletâneas de novelas do mesmo autor. Além disso, também se indica que o lançamento da coletânea comemora o $30^{\circ}$ aniversário do estabelecimento de relações diplomáticas entre a China e o Brasil. A introdução foi escrita por Celso Amorim, então Ministro das Relações Exteriores do Brasil, na qual, além de ressaltar a importância da divulgação das obras de Machado de Assis, pelo seu valor artístico indiscutível, discorre-se sobre a importância e os resultados positivos do intercâmbio cultural e acadêmico entre os dois países.

No prefácio, o embaixador do Brasil na China, Afonso Celso de Ouro Preto, celebra o lançamento da tradução chinesa e agradece ao patrocinador pela sua publicação. Discorre também sobre a composição da obra, indicando que os contos oferecem diferentes reflexões sobre as questões éticas e emocionais levantadas pelo filósofo espanhol José Ortega y Gasset (como se vê, por exemplo, nos contos "O Enfermeiro" e "Pai Contra Mãe"). Além disso, o prefaciador afirma que os temas da maioria dos contos machadianos envolvem o ódio, a vaidade, a degeneração e o desequilíbrio mental bemintencionado (como ocorre, por exemplo, em "O Alienista" e em "A Causa Secreta").

Aliás, a tradução inclui uma nota do patrocinador (José Tadeu de Moraes, Presidente da Samarco Mineração S. A.). Geralmente, para o estudo sobre a tradução e a introdução de algum escritor num país estrangeiro, o papel das editoras e dos patrocinadores é muito importante, já que suas opiniões são capazes de interferir no processo de tradução. No entanto, ao analisar a nota do patrocinador, descobrimos que ela enfatiza a divulgação da cultura brasileira no exterior e a apresentação da própria empresa. Quanto à razão manifestada para o apoio financeiro, o presidente aponta que ele se deu em resposta à iniciativa lançada pela embaixada brasileira na China com 
o motivo da comemoração do $30^{\circ}$ aniversário da relação diplomática entre os dois países.

Diferentemente das outras duas traduções (a tradução de Quincas Borba foi publicada pela Shanghai Translation Publishing House, e a tradução de Dom Casmurro pela Foreign Language Publishing House), a coletânea $O$ alienista e outras histórias saiu pela People's Literature Publishing House. Pelos nomes das editoras, percebe-se que as duas primeiras se dedicam à tradução e à divulgação de obras estrangeiras (como são editoras que recebem subsídios do governo, geralmente não precisam de patrocinadores externos para a publicação desse tipo de obra), enquanto a editora People's Literature Publishing House é apenas uma editora de publicação e divulgação de obras literárias, não tendo verbas específicas em quantidade suficiente, como têm as outras duas, para a tradução e divulgação de obras estrangeiras.

$\mathrm{Na}$ tradução dessa coletânea de contos, descobrimos que, em comparação com a tradução de Dom Casmurro de 2001, realizada pelo mesmo tradutor, existem as seguintes características:

A. A linguagem usada é mais aproximada da língua de chegada. Como já indicamos, na tradução de Dom Casmurro existem casos em que as estruturas frásicas chinesas são parecidas com as estruturas da língua portuguesa. Os casos de estrangeirização nas estruturas frásicas chinesas ainda existe nesta tradução, embora em número mais reduzido.

B. Recurso à tradução direta para os títulos de cada capítulo, muito diferente das mudanças dos títulos encontradas na tradução de Dom Casmurro.

C. Adoção com mais frequência da domesticação. Esse procedimento aparece mais nas explicações das citações do texto-fonte: o tradutor, além de esclarecer a quê ou a quem se referem as citações, em alguns casos, ofereceu informações conotativas ou os seus próprios comentários.

Vejamos os seguintes exemplos:

(1). Explicações das citações nas notas de rodapé:

A. "A proposta colocou o pobre boticário na situação do asno de Buridan" ("O alienista" - ASSIS, 1941, p. 70, grifo nosso). Sobre a conotação desse "asno de Buridan", o tradutor ofereceu uma explicação detalhada com significados conotativos: pôr um asno com fome e sede entre forragem e água, deixando-o escolher só uma; isto é, ou o asno morre de sede, ou morre de fome. Esta situação é imaginada por Jean Buridan, filósofo do século XIV, 
para justificar as liberdades que não têm diferença entre si (ASSIS, 2004, p. 67). ${ }^{9}$ Com isso, o tradutor tenta oferecer a informação conotativa transmitida pelo texto-fonte.

B. "Sabendo o alienista que ele ignorava perfeitamente o hebraico e o grego, incumbiu-o de fazer uma análise crítica da versão dos Setenta; [...]" ("O alienista" - ASSIS, 1941, p. 75, grifo nosso). Além das explicações sobre a que se refere a "versão dos Setenta", o tradutor deixou ainda os seus próprios comentários, o que não ocorre na tradução de Dom Casmurro. Segundo ele, "para avaliar o valor desta versão, é preciso dominar muitas línguas", o Padre Lopes não sabia nada do hebraico e do grego, porém, "ele aceitou a tarefa, o que mostra perfeitamente que ele não tem uma mente clara". Mediante as explicações, os leitores conseguem perceber as conotações transmitidas pelo texto-fonte.

(2). Domesticação e estrangeirização:

A. "A Casa Verde foi o nome dado ao asilo, por alusão à cor das janelas, que pela primeira vez apareciam verdes em Itaguaí. [...]" ("O alienista" ASSIS, 1941, p. 13, grifo nosso). A parte em itálico foi traduzida para o chinês como "desde a altura em que o céu é separado da terra". ${ }^{10} \mathrm{Com}$ isso, o tradutor pretendeu aproximar a tradução dos leitores, já que a imagem empregada está fortemente ligada à mitologia chinesa, segundo a qual, no começo do mundo, o céu e a terra misturam-se como um conjunto.

B. "ninguém deixou de ir visitá-la duas e três vezes, apesar dos costumes caseiros e recatados do século, e não só a cortejavam como a louvavam; [...]" ("O alienista" - ASSIS, 1941, p. 14, grifo nosso). A parte em itálico foi traduzida para "vivem uma vida recatada; podem ouvir os cães e gatos dos vizinhos, mas não se comunicam até à morte", expressão idiomática usada em chinês ${ }^{11}$ para indicar uma situação em que as pessoas não se entendem e não querem comunicar entre si.

C. "[...] enfim, como a não faria o mais atilado corregedor" ("O alienista" - ASSIS, 1941, p. 18, grifo nosso). A parte em itálico foi traduzida para "mesmo o corregedor mais atilado fica tão longe por trás dele, só podendo ver a poeira dele", ${ }^{12}$ indicando uma distância entre duas pessoas em algum aspeto.

\footnotetext{
9 Tradução nossa.

${ }^{10}$ Retradução do chinês para o português nossa.

${ }^{11}$ Retradução do chinês para o português nossa.

12 Retradução do chinês para o português nossa.
} 
Semelhantemente à tradução de Dom Casmurro, nesta tradução, notase também um recurso frequente à domesticação, tornando as palavras ou expressões mais familiares para os leitores chineses.

Aliás, mais uma vez, nota-se a adoção da estrangeirização na tradução de algumas estruturas frásicas. Dado o nosso limite de espaço neste artigo, só iremos citar um exemplo para ilustrar esse elemento:

E. "- [...] Se ele gastou tão depressa o que recebeu, a culpa não é dele.

$-\mathrm{Não}$ ?

- Não, senhor." ("O alienista" - ASSIS, 1941, p. 30)

"他 如此迅速地 把继承来的钱财 挥霍一空, 可过错 并不 在 他。” (ASSIS, 2004, p. 24)

Ele tão depressa o dinheiro recebido gastar, culpa não é dele (tradução palavra por palavra).

"不是 他的 过错?" (ASSIS, 2004, p. 24)

Não dele culpa (tradução palavra por palavra).

"不是, 先生。" (ASSIS, 2004, p. 24)

Não senhor (tradução palavra por palavra).

Pelas traduções, pode observar-se que a estrutura da última frase chinesa é igual à portuguesa, apesar de essa estrutura não ser uma estrutura normal em chinês; ao contrário, ela é um resultado da influência do português. Para as orações interrogativas negativas em chinês, as respostas de "sim" ou "não" são totalmente contrárias às do português. Vejamos um exemplo:

\section{你 不 爱 我吗?}

ch: Você não amar eu? (tradução palavra por palavra).

pt: Você não me ama?

不, 我爱 你。

ch: Não, eu amar tu (tradução palavra por palavra).

pt: Sim, eu amo-te.

是的, 我不爱你。

ch: Sim, eu não amar tu (tradução palavra por palavra).

pt: Não, eu não te amo.

Baseando-se no exemplo dado, convém traduzir a última frase do exemplo (E) para "是的, 先生" (em tradução palavra por palavra: "sim, 
senhor"), que significa em português "não, senhor", funcionando como uma resposta para a oração interrogativa negativa.

\section{Considerações finais}

Embora tenham sido introduzidas muito cedo (1992) para a apreciação dos leitores chineses, até agora só três obras e uma coletânea de contos de Machado de Assis foram traduzidas. Isso, por um lado, se deve às escolhas das editoras, por outro, à linguagem machadiana que apresenta tanto variantes de época como variantes profundamente inovadoras, o que representa, muitas vezes, uma tarefa desafiadora para os tradutores. A maioria dos estudos (apesar de muito escassos) sobre Machado na China, como já indicamos, foca principalmente nas introduções do autor ou das suas obras no país, embora, por vezes, haja também alguns estudiosos mais renovadores que partem dos pontos de vista mais invulgares, como, por exemplo, a análise feminista da personagem Capitu. Mesmo assim, tais estudos relacionados são bem mais escassos do que os estudos em nível mundial sobre este escritor tão importante da história da literatura do Brasil.

Em nossas análises tradutórias, descobrimos que as citações dos textosfonte costumam ser explicadas com notas de rodapé ou esclarecidas entre parênteses depois das próprias palavras. Os títulos dos capítulos às vezes são mudados pelo tradutor (como vimos na tradução de Dom Casmurro, por Li Junbao), embora isso não seja constante (já que na outra tradução, Li não muda nada nos títulos).

A tradução de Sun Cheng'ao tem as seguintes características: (1) adoção tanto da domesticação como da estrangeirização; (2) frases chinesas fluidas sem influência das estruturas frásicas portuguesas; (3) explicações nas notas de rodapé para as citações do texto-fonte. Em comparação com as traduções de Sun, os trabalhos de Li Junbao mostram características nem sempre iguais: (1) adoção da domesticação para algumas palavras e expressões portuguesas; (2) representação estrangeirizadora na versão chinesa, pela influência de algumas estruturas frásicas portuguesas; (3) explicações (no rodapé ou depois das palavras) das citações da versão original em língua portuguesa (sendo as explicações mais detalhadas, com informações conotativas ou comentários do próprio tradutor, no caso da tradução de Contos escolhidos: o alienista e outras histórias); (4) por fim, a intervenção do 
tradutor é fortemente destacada pela adoção do método de ampliação e mudança na tradução dos títulos dos capítulos da obra Dom Casmurro.

\section{Referências}

APRESENTAÇÃO de Sun Cheng'ao. Disponível em: <https://baike.baidu.com/ item/孙成敖/2827511?fr=aladdin>. Acesso em: 11 jul. 2018.

ASSIS, Machado de. O alienista. Lisboa: Editorial Inquérito, 1941. . Quincas Borba. Porto: Livraria Chardron, 1984. . Dom Casmurro. Mem Martins: Europa-América, 1998. ; CHENG'AO, Sun. Quincas Borba. Shanghai: Shanghai Translation Publishing House, 1999. ; JUNBAO, Li. Dom Casmurro. Beijing: Foreign Language Publishing House, 2001.

; _ـ O alienista e outras histórias. Beijing: People's Literature Publishing House, 2004.

CHENG'AO, Sun. Literatura brasileira. Beijing: Foreign Language Teaching and Researching Press, 1999.

JINGDONG, Zhu; CHENG'AO, Sun. História da literatura latino-americana. Tianjin: Editora Montanha das Flores, 2004.

JORGE, Amado; CHENG'AO, Sun. Gabriela, cravo e canela. Shanghai: Shanghai Translation Publishing House, 1985.

QUEM esmagou a cabeça da serpente? Jesus ou Maria?. 6 dez. 2012. Disponível em: $<$ https://padrepauloricardo.org/episodios/quem-esmagou-a-cabeca-da-serpentejesus-ou-maria>. Acesso em: 11 jul. 2018.

SHAN, Sun. Machado de Assis, Dom Casmurro: Rebellion and Overstepping. 8 de agosto de 2016. Disponível em: <http://www.chinawriter.com.cn/nl/2016/0808/ c405173-28617603.html>. Acesso em: 11 jul. 2018.

VENUTI, Lawrence. The Translator's Invisibility: A History of Translation. London; New York: Routledge, 1995.

ZHIHUA HU é doutorando em Tradução e Terminologia pela Universidade de Aveiro (UA) e investigador em formação do Centro de Línguas, Literaturas e Culturas (CLLC) da mesma universidade. E-mail: ramonhu@outlook.com; zhihua.hu@ua.pt 
MARIA TERESA ROBERTO é docente no Departamento de Línguas e Culturas da Universidade de Aveiro (UA), lecionando nas áreas de Língua e Linguística Inglesa, Teoria e Metodologia da Tradução, Tradução Especializada, Terminologia, Línguas de Especialidade e Comunicação Técnica. A sua investigação centra-se nessas áreas, embora não se limite a elas. Dirige o Programa Doutoral de Tradução e Terminologia, uma parceria da UA com a Universidade Nova de Lisboa. É, atualmente, coordenadora da Linha de Investigação em Tradução e Terminologia do Centro de Línguas, Literaturas e Culturas. E-mail: mariateresaroberto@ua.pt

Recebido: 31.07.2018

Aprovado: 19.10.2018 